\title{
T-Cell Lymphoma Presenting in the Breast: A Histologic, Immunophenotypic and Molecular Genetic Study of Four Cases
}

Nadine S.I. Aguilera, M.D., Fattaneh A. Tavassoli, M.D., Wei-Sing Chu, M.D., Susan L. Abbondanzo, M.D. Departments of Hematopathology (NSIA, W-SC, SLA) and Gynecologic and Breast Pathology (FAT), Armed Forces Institute of Pathology, Washington, D.C.

Primary non-Hodgkin's lymphoma of the breast is uncommon. Most primary breast lymphomas are of B-cell phenotype, with only rare cases showing a T-cell phenotype. In this study, we report the clinicopathologic features of four cases of T-cell lymphoma in the breast. The patients all were female with a mean age of 48 years (range, 13 to 77 years). All cases showed immunoreactivity in paraffinembedded tissue for T-cell markers CD3, CD45RO, and CD43. $\beta F 1$ was positive in three of four cases. The four cases were further subclassified as anaplastic large cell lymphoma (CD30 positive) of Timmunophenotype; natural killer/T-cell lymphoma; peripheral T-cell (CD4 positive), large cell type; and peripheral T-cell (CD8 positive, T-cell intracellular antigen positive), medium cell type. Three of the four cases were monoclonal for T-cell receptor $\beta$ and/or T-cell receptor $\gamma$. The one case of natural killer/T-cell lymphoma was negative for monoclonality with both T-cell receptor $\beta$ and $\gamma$ by molecular diagnostic studies. In all cases, IgH was negative. Follow-up was obtained in three cases. Two patients died within less than 1 year after the diagnosis. The third patient died within 18 months of the diagnosis. Our results suggest an aggressive clinical course for T-cell lymphomas that present in the breast.

KEY WORDS: Breast lymphoma, Natural killer/Tcell, T-cell lymphoma.

Mod Pathol 2000;13(6):599-605

Copyright $\odot 2000$ by The United States and Canadian Academy of Pathology, Inc.

VOL. 13, NO. 6, P. 599, 2000 Printed in the U.S.A.

Date of acceptance: November 29, 1999.

The opinions and assertions contained herein are the private views of the authors and are not to be construed as official or as reflecting the views of the Department of Air Force, the Department of Army, or the Department of Defense.

Address reprint requests to: Nadine S.I. Aguilera, M.D., Department of Hematopathology, Armed Forces Institute of Pathology, Building 54, Washington, DC 20306-6000; Fax: 202-782-9157.
Non-Hodgkin's lymphoma (NHL) of the breast is uncommon, composing 0.04 to $0.5 \%$ of all malignant breast tumors (1-5). Most primary breast lymphomas are of B-cell phenotype or have not been immunophenotyped; only rare cases have been reported as T-cell in series of lymphomas of the breast (1-38). Single case reports of T-cell lymphoma of the breast also are found in the literature (39-47). Reports have included lymphoblastic lymphoma (1, 3, 9); anaplastic large cell (ALCL) (CD30 positive) $(13,14,47)$; peripheral T-cell (PTCL; including large cell, pleomorphic, and high grade) (8, 14-17, 39, 40, 45, 46); adult T-cell, human T-cell lymphoma-related (41); multilobated (42); and mycosis fungoides $(43,44)$.

The pathobiology of T-cell lymphoma in the breast is poorly understood because of the limited number of cases available for study. With the increasing availability of T-cell markers for paraffinembedded tissue, however, archival material can be more readily examined and subtyped. We present four cases of lymphoma with a T-cell and/or natural killer (NK) cell phenotype. All cases described in this article presented as mass lesions within breast parenchyma. The lymphomas followed an aggressive clinical course in the patients with available clinical follow-up.

\section{MATERIALS AND METHODS}

Four cases of T-cell lymphoma that occurred in the breast were retrieved from the files of the Armed Forces Institute of Pathology from 1990 to 1999. Blocks were available on all cases for immunohistochemical and genotypic studies.

\section{Immunohistochemistry}

Five-micron sections from paraffin-embedded tissue blocks were prepared for immunophenotypic analysis. Immunohistochemistry was performed according to the standard avidin-biotin complex 
method of Hsu et al. (48). Sections were incubated at room temperature for $30 \mathrm{~min}$ with the following antibody panel for each case: CD45RB, CD20, CD45RO, CD3, CD43, $\beta \mathrm{F} 1$, and cytokeratin. CD30, anaplastic lymphoma kinase (ALK-1), T-cell intracellular antigen (TIA-1), CD4, CD8, CD56, T-cell receptor (TCR) $\delta$-1, latent membrane protein for Epstein-Barr virus, and epithelial membrane antigen were performed in selected cases (see Table 1). Of the above antibodies, CD3, CD30, and $\beta F 1$ required predigestion for $20 \mathrm{~min}$ with $0.4 \%$ Pepsin (\#P-7000; Sigma Chemical Co., St. Louis, MO) in $0.1 \mathrm{M} \mathrm{HCl}$ buffer solution ( $\mathrm{pH} 2.0$ ) at 40 to $42^{\circ} \mathrm{C}$. Microwave antigen retrieval, heated for $10 \mathrm{~min}$ in $10 \mathrm{mmol} / \mathrm{L}$ citrate buffer at $\mathrm{pH} 6.0$, was necessary for CD56, ALK-1, TIA-1, CD4, CD8, and TCR $\delta$-1 (49). All reactions were developed with 3,3diaminobenzidine tetrahydrochloride using a 3,3' diaminobenzidine chromogen kit (\#K3466; DAKO, Carpinteria, CA).

Positive immunoreactivity for CD45RB and T-cell markers CD3, CD45RO, or $\beta$ F1 with negative CD20 was used to determine T-cell immunophenotype.

\section{Molecular Diagnostic Studies}

Molecular diagnostic studies were performed by polymerase chain reaction (PCR) from formalinfixed, paraffin-embedded tissue for Ig heavy chain (IgH), TCR $\beta$, and TCR $\gamma$ by previously established methods (50).

\section{In Situ Hybridization Studies}

In situ hybridization for the presence of EpsteinBarr virus-encoded RNA was performed on sec-

TABLE 1. Antibodies

\begin{tabular}{|c|c|c|}
\hline Antibody & Source & Dilution \\
\hline $\mathrm{CD} 45 \mathrm{RB}(\mathrm{LCA})^{a}$ & DAKO, Carpinteria, CA & $1: 200$ \\
\hline $\mathrm{CD} 20(\mathrm{~L} 26)^{a}$ & DAKO & $1: 200$ \\
\hline $\mathrm{CD} 45 \mathrm{RO}(\mathrm{UCHL}-1)^{a}$ & DAKO & $1: 200$ \\
\hline $\mathrm{CD}^{b, c}$ & DAKO & $1: 500$ \\
\hline CD43(MT-1) ${ }^{a}$ & Biotest, Denville, NJ & $1: 50$ \\
\hline$\beta \mathrm{F}-1(8 \mathrm{~A} 3)^{a, c}$ & Endogen, Woburn, MA & $1: 50$ \\
\hline CD30(Ber H2) ${ }^{a, c}$ & DAKO & $1: 100$ \\
\hline Cytokeratin(AE1/AE3) ${ }^{a, c}$ & Boehringer, Indianapolis, IN & $1: 400$ \\
\hline TIA- $1^{a, d}$ & Coulter, Miami, FL & $1: 400$ \\
\hline $\mathrm{CD} 4^{a, d}$ & Vector (Novocastra), Burlingame, CA & $1: 500$ \\
\hline $\mathrm{ALK}_{-1}{ }^{a, d}$ & DAKO & $1: 100$ \\
\hline $\mathrm{CD}^{a, d}$ & DAKO & $1: 100$ \\
\hline TCR $\delta$-1(TCR1061) ${ }^{a, d}$ & Endogen & $1: 10$ \\
\hline $\mathrm{LMP}_{-1}{ }^{a, c}$ & DAKO & $1: 50$ \\
\hline $\mathrm{EMA}^{a}$ & DAKO & $1: 100$ \\
\hline $\mathrm{CD}_{5} 6^{a, d}$ & Caltag, Burlingame, CA & $1: 100$ \\
\hline \multicolumn{3}{|c|}{$\begin{array}{l}\text { LCA, leukocyte common antigen; TIA, T-cell intracellular antigen; ALK, } \\
\text { anaplastic lymphoma kinase; TCR, T-cell receptor; LMP, latent membrane } \\
\text { protein; EMA, epithelial membrane antigen. } \\
\text { Clones are in parentheses. } \\
{ }^{a} \text { Mouse monoclonal. } \\
{ }^{b} \text { Rabbit polyclonal. } \\
{ }^{c} \text { Required predigestion for } 20 \text { minutes with } 0.4 \% \text { Pepsin. } \\
{ }^{d} \text { Microwave antigen retrieval. }\end{array}$} \\
\hline
\end{tabular}

tions of formalin-fixed paraffin-embedded tissue using an Epstein-Barr virus-encoded RNA in situ kit (DA160SS; BioGenex, San Ramon, CA) according to the manufacturer's instructions. Appropriate positive and negative controls were preformed simultaneously and stained according to the kit instructions.

\section{RESULTS}

\section{Case 1}

A 13-year-old Asian female who initially was believed to have a breast infection developed a fungating mass that was excised. The initial tissue diagnosis was an undifferentiated sarcoma, but immunohistochemical studies revealed a lymphoma, ALCL, CD30-positive, T-cell phenotype. The patient developed a lung mass within 5 months after excision of the mammary tumor. The lung mass was dissemination of the original lymphoma. The patient died shortly thereafter with diffuse pulmonary infiltrates and pleural involvement by the malignancy.

A $6.0 \times 6.0-\mathrm{cm}$ fungating mass involved the left breast with extensive epidermal necrosis. The cells infiltrating the tissue were large and monomorphic with focal areas of myxoid change in the background (Fig. 1). Rare Hodgkin's-like cells were present. Necrosis and inflammation were extensive. The cells were immunoreactive with CD45RB, CD30, CD45RO, CD43, ALK-1, TIA-1, epithelial membrane antigen, and $\beta \mathrm{F} 1$ (Fig. 2). CD3 was focally immunoreactive. CD20 and CD56 were negative. The malignant lymphoma was within the breast tissue near the epithelium, but cytokeratin did not show a lymphoepithelial (LE) component. The molecular genetic IgH assay was nonamplifi-

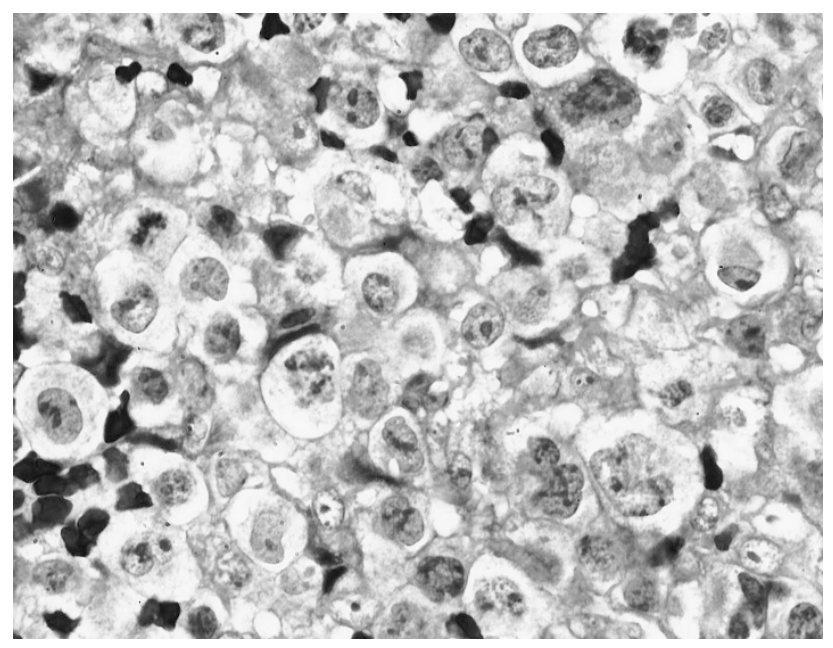

FIGURE 1. Case 1 of anaplastic large cell lymphoma showing numerous large cells with abundant cytoplasm. Many of the cells were monomorphic with scattered rare pleomorphic cells. 


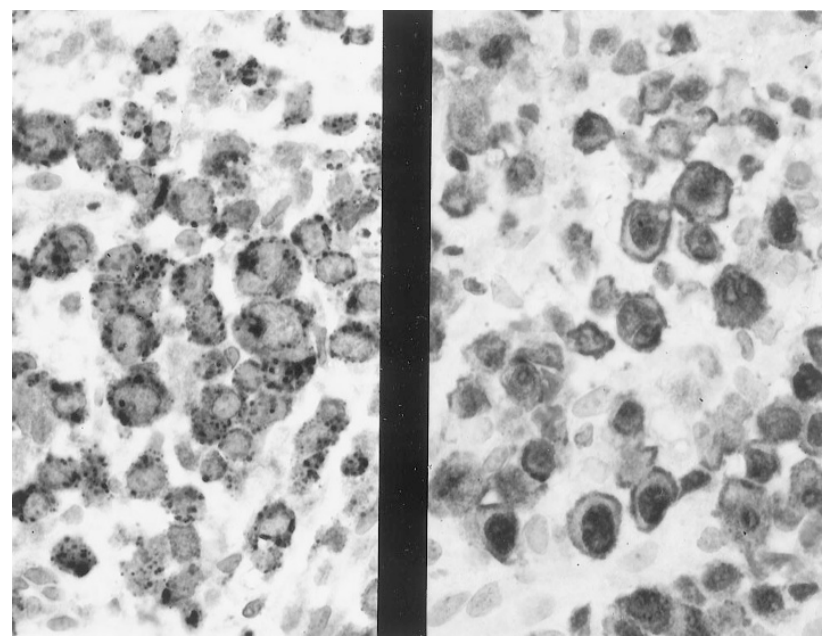

FIGURE 2. Case 1 showing anaplastic lymphoma kinase with nuclear and cytoplasmic immunoreactivity (right) and T-cell intracellular antigen (left) immunoreactivity.

able. TCR $\beta$ and $\gamma$ assays showed a monoclonal band.

\section{Case 2}

A 56-year-old Caucasian woman presented with a right breast mass and an enlarged axillary lymph node. The patient underwent a needle biopsy with a subsequent excisional biopsy, and a diagnosis of a T-cell lymphoma was rendered. The patient died with disease 3 months after the excisional biopsy.

A nodular proliferation of atypical clear cells of intermediate size with abundant interspersed histiocytes was present in the malignant T-cells and infiltrated the breast parenchyma and fat (Figs. 3 and 4). The lymphoma seemed to follow the lobular breast architecture and the associated fibrosis accentuated in the striking nodularity. The axillary lymph node showed effacement of the architecture by the same infiltrate seen in the breast tissue.

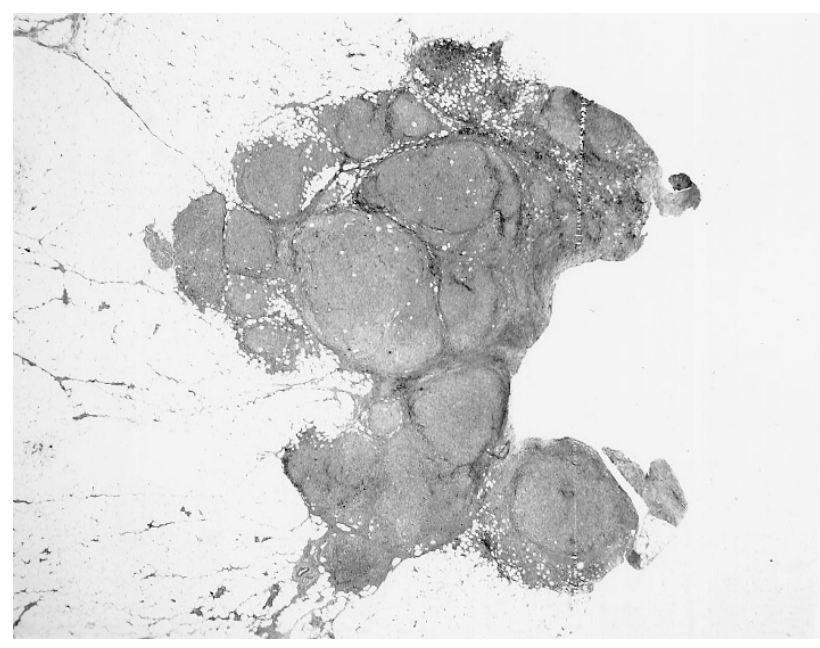

FIGURE 3. A low-power view of Case 2, which shows the nodular appearance of the lymphoma with extension into the fat.

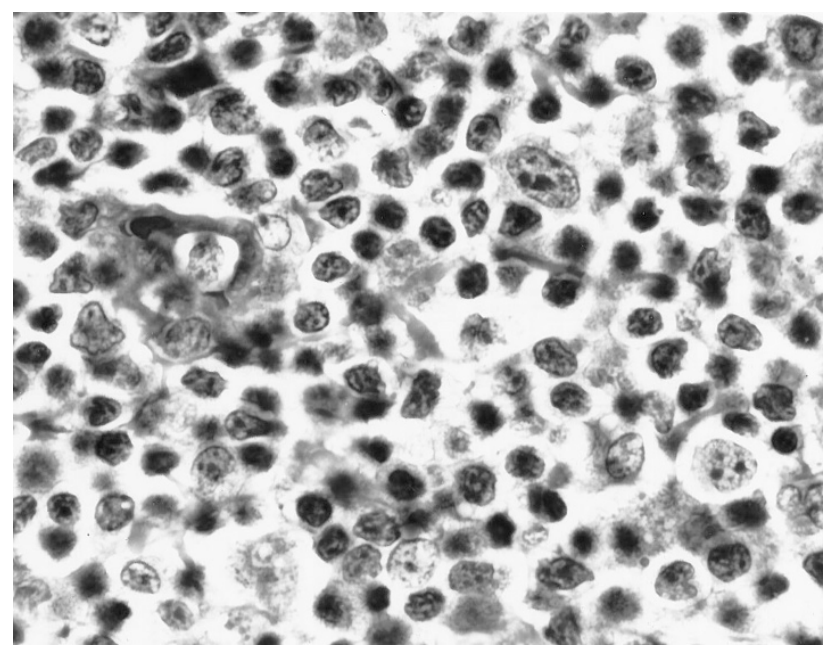

FIGURE 4. High-power field of Case 2 showing intermediate-sized lymphocytes with abundant cytoplasm and atypia.

Numerous epithelioid histiocytes were seen throughout the malignant cells of the lymph node. Because of the numerous epithelioid histiocytes, the case initially was diagnosed as a peripheral T-cell lymphoma, lymphoepithelioid cell ("Lennert's" lymphoma); we reclassified the case as PTCL, medium cell. Immunohistochemical studies showed that the malignant cells were immunoreactive with CD45RB, CD3, CD45RO, $\beta$ F1, CD43, CD8, and TIA-1. Rare cells were immunoreactive with CD30. CD56 was weakly immunoreactive in $20 \%$ of the cells. The cells were negative with CD20, CD4, TCR $\delta$-1, and cytokeratin. CD20 highlighted sparse B cells, which were found at the periphery of the nodules in the breast. No evaluation for LE components could be made in the breast mass because the unstained slides were limited. The TCR $\gamma$ assay showed a monoclonal band. The IgH assay and TCR $\beta$ assays showed no monoclonal band.

\section{Case 3}

A 44-year-old woman of unknown ethnic background presented with a left breast lump. A simultaneous lung lesion was detected. An excisional biopsy of the breast and a transbronchial biopsy of the lung were performed. The patient initially was believed to have a carcinoma of the breast with metastasis to the lung but on histologic examination was diagnosed as having a "peripheral T-cell lymphoma." The patient was given an autologous bone marrow transplant 2 months after the diagnosis but was subsequently found to have residual or recurrent lymphoma. Salvage treatment was given, but the patient died 18 months after the initial diagnosis of lymphoma. No autopsy was performed.

The breast lobules and soft tissue were infiltrated with a malignant population of medium-sized lym- 
phocytes with abundant clear cytoplasm (Figs. 5 and 6). The lobular infiltrate gave the appearance of LE lesions (Fig. 7). The cells in the bronchial biopsy had a similar appearance. No necrosis or vascular invasion was present. The malignant cells were immunoreactive with CD45RB (weak), CD3, CD43, TIA-1, and CD56 (Fig. 8). The cells were negative with CD20, CD45RO, $\beta$ F1, TCR $\delta$, CD30, CD4, CD8, latent membrane protein for Epstein-Barr virus, and cytokeratin. The diagnosis was revised to NK/ T-cell lymphoma. No monoclonal band was found in the IgH or the TCR $\beta$ or $\gamma$ assay. The in situ hybridization study for Epstein-Barr virus-encoded RNA was negative.

\section{Case 4}

A 77-year-old woman of unknown ethnic background presented with a right breast mass, which had been present for approximately 12 months. Several core biopsies of the mass were performed. At the time the mass was biopsied, it was noted that several $1-\mathrm{cm}$ axillary lymph nodes were present but there was no history of lymphoma. The bone marrow was negative. Four months after diagnosis, widespread lymphadenopathy developed. The patient refused treatment, and no further follow-up could be obtained.

The core biopsies showed a vaguely nodular proliferation of small lymphocytes in adipose tissue. Elsewhere in the core, a small lymph node with a malignant population of $\mathrm{T}$ cells in a "T-zone" pattern was identified (Fig. 9). The malignant cells were intermediate in size with abundant clear cytoplasm (Fig. 10). Atretic germinal centers and sinuses also were present in these areas, confirming the impression of an intramammary lymph node. The lymphoid proliferation was CD45RB positive. The germinal centers were immunoreactive with



FIGURE 5. Case 3 of natural killer/T-cell lymphoma shows lobular pattern of infiltration of the lymphoma at low power.

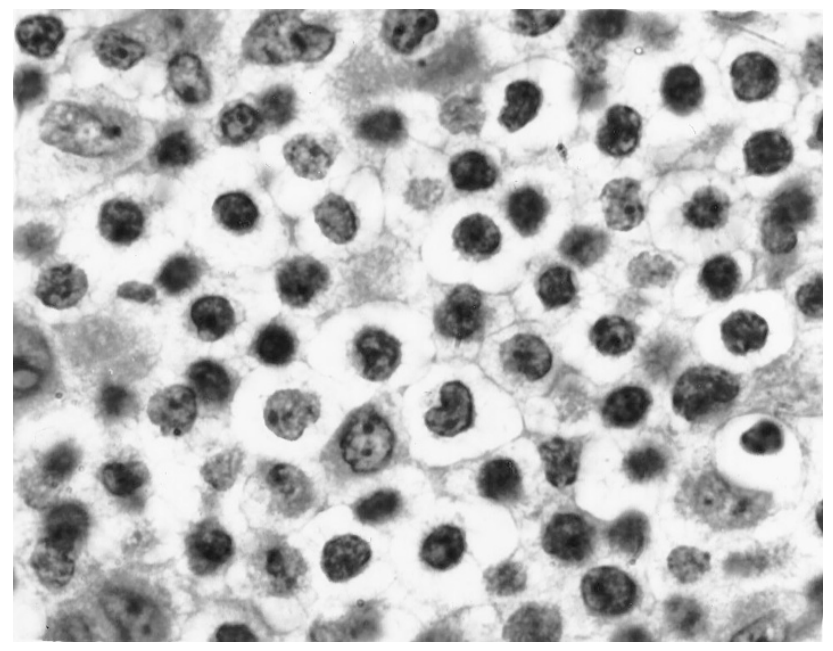

FIGURE 6. Case 3 at higher power showing lymphocytes with abundant clear cytoplasm and irregular nuclei.

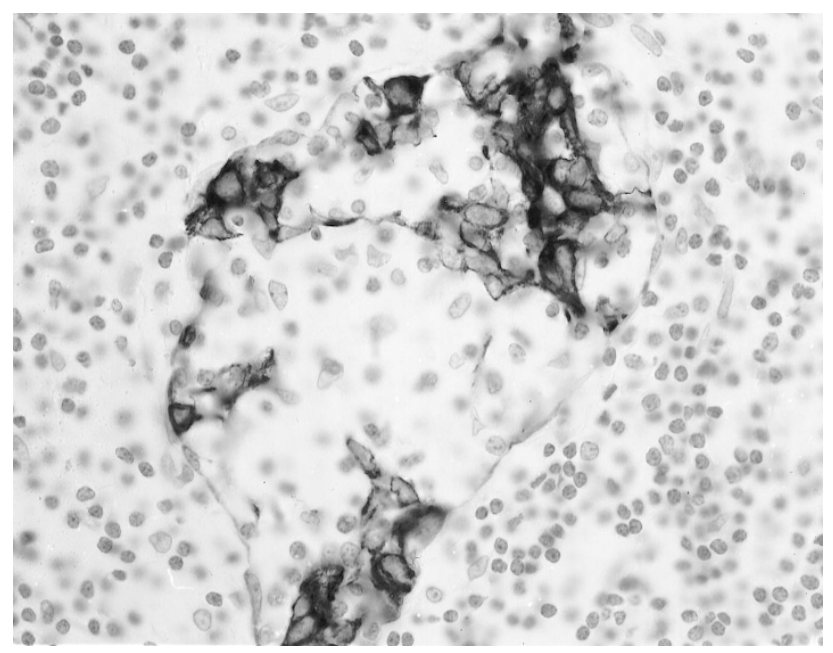

FIGURE 7. The pankeratin immunohistochemical maker highlights lymphoepithelial lesions in Case 3.

CD20. The internodular areas were immunoreactive with CD3, CD45RO, CD4, and CD43, $\beta \mathrm{F} 1 \mathrm{im}$ munoreactive. CD30, CD8, CD56, and TIA-1 were negative. The cytokeratin did not show an LE component. The diagnosis was peripheral T-cell lymphoma, large cell type. The molecular genetic assay for IgH was negative. The assay for TCR $\beta$ showed a monoclonal band with two DJ primers. TCR $\gamma$ could not be performed because the DNA was nonamplifiable. Cases are summarized in Tables 2 and 3.

\section{DISCUSSION}

Peripheral T-cell lymphomas compose less than $15 \%$ of all non-Hodgkin's lymphomas (51) and are extremely rare in the breast, representing 0.04 to $0.5 \%$ of all breast malignancies (1-5). T-cell lymphomas, particularly nodal peripheral T-cell lymphomas, have an aggressive course and usually present with generalized disease, although some 


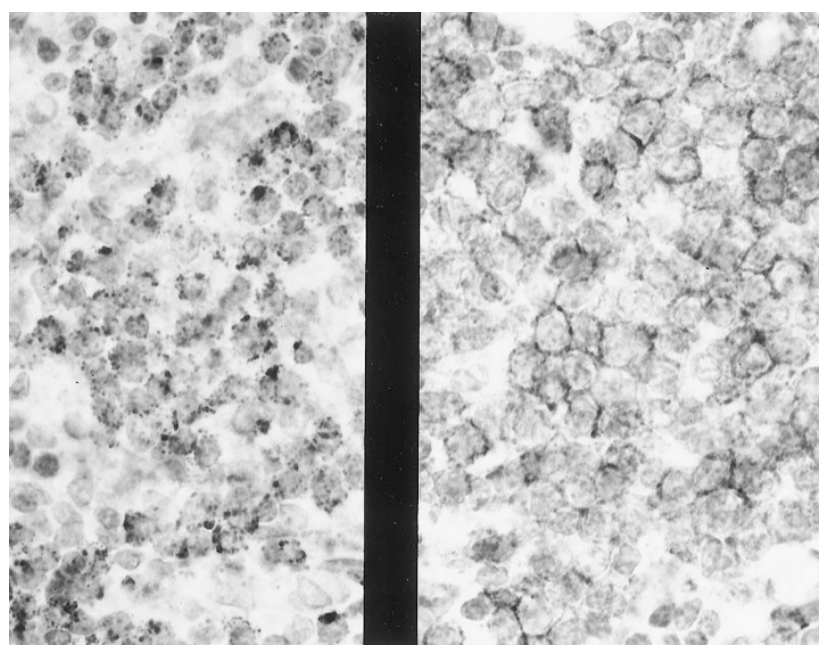

FIGURE 8. Case 3 showing immunoreactivity with CD56 (right) and $\mathrm{T}$-cell intracellular antigen (left).

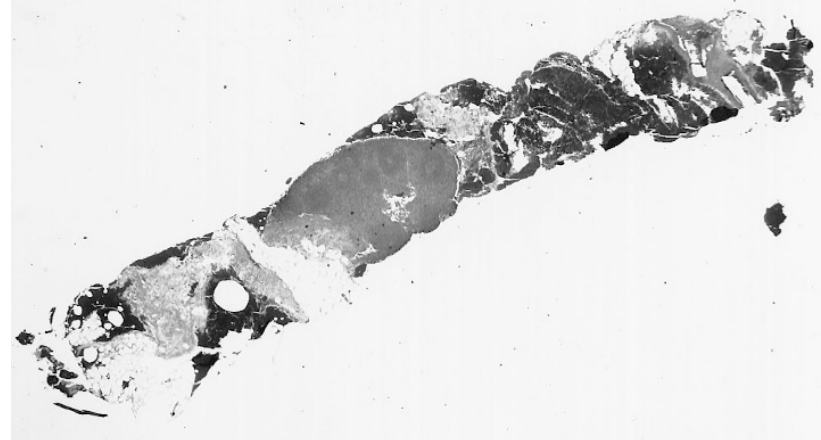

FIGURE 9. Low-power view of one of the core biopsies in Case 4 showing a lymph node surrounded by neoplastic cells.

subtypes may be less malevolent in behavior (51). Lymphomas such as ALCL and NK/T-cell type, which often are extranodal, have variable clinical behavior but in general have at least an intermediately aggressive clinical behavior. Little is known about nonpanniculitic lymphomas of $\alpha \beta$, CD8 phenotype, as described in Case 2. The T-cell lymphomas in the breast, which we present in this study, seem to represent the aggressive end of the spectrum in these neoplasms, regardless of subtype.

Anaplastic large cell lymphoma, as in Case 1, has been reported previously in two series $(13,14)$ and one case report (47). Whether, in our case, the skin involvement was primary or secondary to the underlying malignancy could not be determined with our specimen. No nodal disease was found. The neoplasm was aggressive and was immunoreactive with ALK-1 and epithelial membrane antigen, which indicates a systemic ALCL rather than a primary cutaneous ALCL (52).

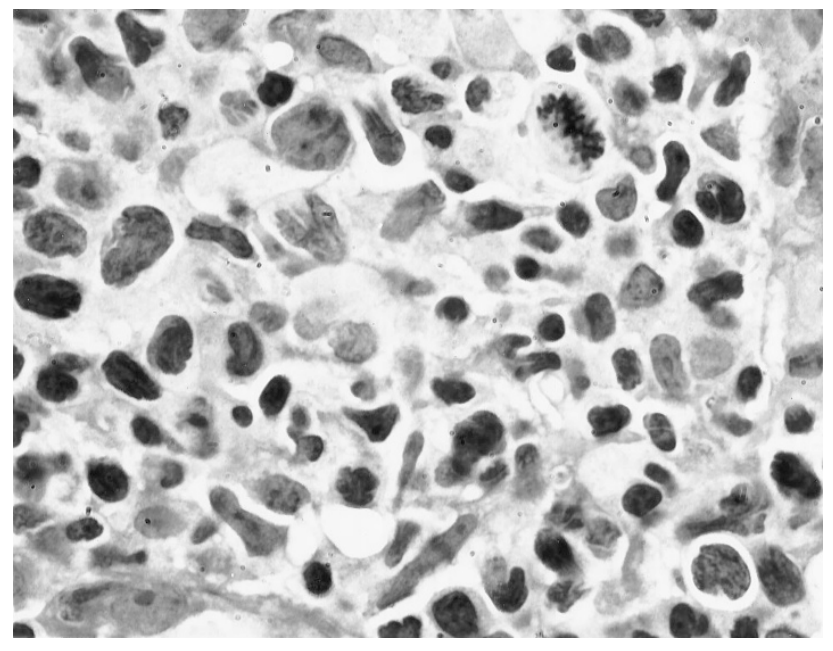

FIGURE 10. Case 4 showing atypical cells exhibiting mitoses and clear cytoplasm.

Previous cases of mammary T-cell lymphoma with CD8 immunoreactivity, as in Case 2, have been reported by Cohen and Brooks (2) and Vasei et al. (39). TIA-1 was not performed in the previous reports. Case 2 herein of CD8-positive and TIA-1 immunoreactive T-cell lymphoma is similar in immunophenotype to the so-called panniculitis-like T-cell lymphoma (53), but our case lacked several features of panniculitis-like T-cell lymphoma, namely necrosis and rimming of fat cells by the malignant T-cells. TIA-1 has been reported to be positive in nodal cases of PTCL of lymphoepithelioid type (54) (a diagnosis initially made in Case 2), but we are not aware of any documentation confirming the CD8 immunophenotype in cases of PTCL with a high content of epithelioid histiocytes. This particular type of T-cell may have a predilection for subcutaneous tissues, and the breast may be a natural haven for CD8-positive T-cells. However, this type of lymphoma is exceedingly rare and the present case is only the third such case reported. Further characterization of specific T-cell populations in the breast may be necessary to draw any conclusions.

To our knowledge, no cases of NK/T-cell lymphoma have been reported in the breast, making Case 3 unique. Case 3 showed extensive LE lesions, which has been reported in two other cases of mammary T-cell lymphoma, mycosis fungoides and an unspecified type $(39,43)$. Although we believed that this finding could be confused with marginal zone B-cell lymphoma, mucosa-associated lymphoid tissue type (MZBCL), in one previous study no LE lesions were seen in MZBCL (15) but germinal centers were present. Other studies have described less florid LE lesions in breast lymphoma including MZBCL $(1,2,29)$. We did not see necrosis or vascular invasion characteristic of NK/T-cell lymphomas. The absence of germinal centers and 
TABLE 2. Clinical Information

\begin{tabular}{ccll}
\hline Case & Age/sex & \multicolumn{1}{c}{ Site } & \multicolumn{1}{c}{ Diagnosis } \\
\hline 1 & $13 / \mathrm{F}$ & Lt breast & ALCL, CD30+, T-cell (ALK-1+, TIA-1+) \\
2 & $56 / \mathrm{F}$ & Rt breast/axillary LN & PTCL, medium cell $(\beta$ F1+, CD8+, TIA-1+) \\
3 & $44 / \mathrm{F}$ & Lt breast/lung & NK/T (CD56+, TIA-1+, CD4-, CD8-) \\
4 & $77 / \mathrm{F}$ & Rt breast & PTCL, large cell $($ CD,$+ \beta$ F1+) \\
\hline
\end{tabular}

F, female; Lt, left; Rt, right; LN, lymph node; ALCL, anaplastic large cell lymphoma; PTCL, peripheral T-cell lymphoma; ALK, anaplastic lymphoma kinase; TIA, T-cell intracellular antigen; NK/T, natural killer cell/T-cell lymphoma; DOD, died of disease; +, immunoreactive; -, negative.

TABLE 3. Immunohistochemistry

\begin{tabular}{|c|c|c|c|c|c|c|c|c|c|c|c|c|c|c|}
\hline Case & CD45RB & CD3 & CD4 & CD8 & CD43 & CD45RO & $\beta \mathrm{F} 1$ & TCR $\delta-1$ & CD30 & CD56 & TIA-1 & LMP-1 & ALK-1 & EMA \\
\hline 1 & + & + focal & Neg & Neg & + & + & + & ND & + & Neg & + & ND & + & $+\mathrm{w}$ \\
\hline 2 & + & + & Neg & + & + & + & + & Neg & + rare & $+20 \%$ & + & ND & ND & ND \\
\hline 3 & + & + & Neg & Neg & + & Neg & Neg & Neg & Neg & $+90 \%$ & + & Neg & ND & ND \\
\hline 4 & + & + & + & $\mathrm{Neg}$ & + & + & + & ND & $\mathrm{Neg}$ & Neg & Neg & ND & ND & ND \\
\hline
\end{tabular}

+, immunoreactive; Neg, negative; ND, not done; w, weak; TCR, T-cell receptor; TIA, T-cell intracellular antigen; LMP, latent membrane protein; ALK, anaplastic lymphoma kinase; EMA, epithelial membrane antigen.

the florid LE lesions in our case were helpful in distinguishing T-cell lymphoma from MZBCL.

Case 4 was a common type of PTCL with CD4 and $\beta \mathrm{F} 1$ immunophenotype. Although also rare in the breast, this type of lymphoma was reported in one series (40), but most series reporting breast lymphoma only rarely report T-cell immunophenotype and do not characterize the CD4 or CD8 reactivity of the lymphoma. The architecture of Case 4 suggests that it may have arisen in a mammary lymph node rather than in the breast tissue.

It is interesting that Cases 1,2 , and 3 were immunoreactive for TIA-1, a marker most often seen in extranodal T-cell lymphomas, commonly with a CD8 immunophenotype, of NK-cell origin or ALCL $(52,55)$. Therefore, it is not contradictory that in Case 4, a lymphoma most likely to be nodal, TIA-1 was absent.

The origin of T-cells, which give rise to lymphoma in the breast, remains unresolved. Examination of normal breast shows scattered histiocytes and $\mathrm{T}$ cells, which may be the origin of T-cell lymphoma (56). Mammary lymph nodes giving rise to T-cell lymphoma, and showing obliteration of the architecture or the overlying skin (particularly in regard to NK/T-cell and ALCL) also are plausible origins for this type of lymphoma. Although all of our cases presented in breast and involved the breast tissue, the site of inception is uncertain. Examination of normal T-cell populations and further study of these malignancies in the breast may help elucidate the origin and behavior of these exceedingly rare lymphomas.

\section{REFERENCES}

1. Hugh JC, Jackson FI, Hanson JPS. Primary breast lymphoma. An immunologic study of 20 new cases. Cancer 1990;66: 2602-11.

2. Cohen PL, Brooks JJ. Lymphomas of the breast. A clinico- pathologic and immunohistochemical study of primary and secondary cases. Cancer 1991;67:1359-69.

3. Arber DA, Simpson JF, Weiss LM, Rappaport H. NonHodgkin's lymphoma involving the breast. Am J Surg Pathol 1994;18:288-95.

4. Wiseman C, Liao KT. Primary lymphoma of the breast. Cancer 1972;29:1705-12.

5. Adair FE, Herrmann JB. Primary lymphosarcoma of the breast. Surgery 1944;16:836-53.

6. Aozasa K, Ohsawa M, Saeki K, Horiuchi K, Kawano K, Taguchi T. Malignant lymphoma of the breast: immunologic type and association with lymphocytic mastopathy. Am J Clin Pathol 1992;97:699-704.

7. Harkin DW, Somerville J, Stokes M. Primary breast lymphoma. Ulster Med J 1998;67:61-2.

8. Lands RH. Primary non-Hodgkin's lymphoma of the breast. Tenn Med 1998;91:283.

9. Carbone A, Volpe R, Tirelli U, Veronesi A, Galligioni E, Trovo MG, et al. Primary lymphoblastic lymphoma of the breast. Clin Oncol 1982;8:367-73.

10. Giardini R, Piccolo C, Rilke F. Primary non-Hodgkin's lymphoma of the female breast. Cancer 1992;69:725-35.

11. Bobrow LG, Richards MA, Happerfield LC, Diss TC, Isaacson PG, Lammie GA, et al. Breast lymphomas: a clinicopathologic review. Hum Pathol 1993;24:274-8.

12. Rooney N, Snead D, Goodman S, Webb AJ. Primary breast lymphoma with skin involvement arising in lymphocytic lobulitis. Histopathology 1994;24:81-4.

13. Tan PH, Sng ITY. Breast lymphoma-a pathologic study of 14 cases. Ann Acad Med Singapore 1996;25:783-90.

14. Lin Y, Govindan R, Hess JL. Malignant hematopoietic breast tumors. Am J Clin Pathol 1997;107:177-86.

15. Mattia AR, Ferry JA, Harris NL. Breast lymphoma: a B-cell spectrum including the low grade B-cell lymphoma of mucosa associated lymphoid tissue. Am J Surg Pathol 1993;17: 574-87.

16. Vianello F, Sgarabotto D, Stefani PM, Radossi P, Sartori R, Sartori D, et al. Primary breast lymphoma. Forum (Genova) 1998;8:188-95.

17. Jeon HJ, Akagi T, Hoshida Y, Hayashi K, Yoshino T, Tanaka T, et al. Primary non-Hodgkin malignant lymphoma of the breast. Cancer 1992;70:2451-9.

18. Freeman C, Berg JW, Cutler SJ. Occurrence and prognosis of extranodal lymphomas. Cancer 1999;29:252-60.

19. Mambo NC, Burke JS, Butler JJ. Primary malignant lymphomas of the breast. Cancer 1977;39:2033-40.

20. Abbondanzo SL, Seidman JD, Lefkowitz M, Tavassoli FA, 
Krishnan J. Primary diffuse large B-cell lymphoma of the breast. A clinicopathologic study of 31 cases. Pathol Res Pract 1996;192:37-43.

21. Tanaka T, Hsueh CL, Hayashi K, Awai M, Nishihara K, Konaga E, et al. Primary malignant lymphoma of the breast with a review of 73 cases among Japanese subjects. Acta Pathol Jpn 1984;34:361-73.

22. Brustein S, Kimmel M, Lieberman PH, Filippa DA, Rosen PP. Malignant lymphoma of the breast. A study of 53 patients. Ann Surg 1987;205:144-50.

23. Dyson BC. Periductal mastitis associated with reticulum-cell sarcoma in the breast. Surgery 1961;50:634-8.

24. Tateno M, Yoshiki T, Itoh T, Takamuro M, Saito C. A case of primary B-cell lymphoma of the breast. Cancer 1983;52: 671-4.

25. Schouten JT, Weese JL, Carbone PP. Lymphoma of the breast. Ann Surg 1981;194:749-53.

26. DeCosse JJ, Berg JW, Fracchia AA, Farrow JH. Primary lymphosarcoma of the breast. A review of 14 cases. Cancer 1962;15:1264-8.

27. Elavathil LJ, Kahn HJ, Hanna W. Primary multilobulated B-cell lymphoma of the breast. Arch Pathol Lab Med 1989; 113:1081-4.

28. Eskelinen M, Collán Y, Puittinen J, Pajarinen P, Alhava E. Lymphoma of the breast. Ann Chirurg Gynaecol 1989;78: 149-52.

29. Lamovec J, Jancar J. Primary lymphoma of the breast: lymphoma of the mucosa-associated lymphoid tissue. Cancer 1987;60:3033-41.

30. Telesinghe PU, Anthony PP. Primary lymphoma of the breast. Histopathology 1985;9:297-307.

31. Hofman WI, Goodman ML. Primary lymphoma of the breast. Arch Surg 1968;96:410-3.

32. Souza LJ, Talvalkar GV, Morjaria JH. Primary malignant lymphoma of the breast. Int J Cancer 1978;15:30-5.

33. Dixon JM, Lumsden AB, Krajewski A, Elton RA, Anderson TJ. Primary lymphoma of the breast. Br J Surg 1987;74:214-7.

34. Smith MR, Brustein S, Straus DJ. Localized non-Hodgkin's lymphoma of the breast. Cancer 1987;59:351-4.

35. Alm P, Brandt L, Olsson H. Immunoglobulin-a producing probable primary lymphoma of the breast. Virchows Arch A (Pathol Anat) 1983;399:355-60.

36. Jernstrom P, Sether JM. Primary lymphosarcoma of the mammary gland. JAMA 1967;201:503-6.

37. Bucciarelli E, Cavaliere A, Sidoni A, Alberti PF, Sfondalmondo S. Bilateral primary malignant lymphoma of the breast: a case report. Tumori 1988;74:581-91.

38. Oberman HA. Primary lymphoreticular neoplasms of the breast. Surg Gynecol Obstet 1966;123:1047-51.

39. Vasei M, Kumar PV, Malekhosseini SA, Amirghofran Z. Primary T-cell lymphoma of the breast with lymphoepithelial lesion. APMIS 1997;105:445-8.

40. Anania G, Baccarani U, Risaliti A, Terrosu G, Donini A, Mariuzzi L, et al. Primary non-Hodgkin's T-cell lymphoma of the breast. Eur J Surg 1997;163:633-5.
41. Kosaka M, Tsuchihashi N, Takishita M, Miyamoto Y, Okagawa K, Gotoh T, et al. Primary adult T-cell lymphoma of the breast. Acta Haematol 1992;87:202-5.

42. Pettinato G, Manivel JC, Petrella G, De Chiara A. Primary multilobated T-cell lymphoma of the breast diagnosed by fine needle aspiration cytology and immunocytochemistry. Acta Cytol 1991;35:294-9.

43. Jaspars LH, Bonnet P, Willemze R, Meijer CJLM. Mycosis fungoides with extracutaneous localization in the breast. $\mathrm{Br} \mathrm{J}$ Dermatol 1996;134:1125-30.

44. Jaimovich L, Beruschi MP, Sanguinetti O, Woscoff A. Mammary gland involvement in mycosis fungoides. Int J Dermatol 1991;30:656-7.

45. Sung DW, Lim JW, Yoon Y, Kim YW, Lee JH, Cho KS. Primary breast lymphoma. J Korean Med Sci 1993;8:210-3.

46. Ko YH, Lee JDL. Peripheral T-cell lymphomas. J Korean Med Sci 1991;6:329-37.

47. Pillay P, Chetty R. Anaplastic large cell lymphoma of the breast. Int J Surg Pathol 1999;7:171-4.

48. Hsu SM, Raine L, Fanger H. Use of avidin-biotin-peroxidase complex (ABC) in immunoperoxidase techniques: a comparison between $\mathrm{ABC}$ and unlabeled antibody (PAP) procedures. J Histochem Cytochem 1981;29:577-80.

49. Shi S-R, Key ME, Kalra KL. Antigen retrieval in formalinfixed, paraffin-embedded tissues: an enhancement method for immunohistochemical staining based on microwave oven heating of tissue sections. J Histochem Cytochem 1991; 39:741-84.

50. Abruzzo LV, Griffith LM, Nandedkar M, Aguilera NS, Taubenberger JK, Raffeld M, et al. Histologically discordant lymphomas with B-cell and T-cell components. Am J Clin Pathol 1997;108:316-23.

51. Harris NL, Jaffe ES, Stein J, Banks PM, Chan JKC, Cleary ML, et al. A revised European-American classification of lymphoid neoplasms: a proposal from the International Lymphoma Study Group. Blood 1999;84:1361-92.

52. Kinney MC, Kadin ME. The pathologic and clinical spectrum of anaplastic large cell lymphoma and correlation with ALK gene dysregulation. Am J Clin Pathol 1999;111(Suppl 1):S5667.

53. Salhany KE, Macon WR, Choi JK, Elenitsas R, Lessin SR, Felger RE, et al. Subcutaneous panniculitis-like T-cell lymphoma: clinicopathologic, immunophenotypic, and genotypic analysis of alpha/beta and gamma/delta subtypes. Am J Surg Pathol 1998;22:881-93.

54. Kagami Y, Suzuki R, Taji H, Yatabe Y, Takeuchi T, Maeda S, et al. Nodal cytotoxic lymphoma spectrum. A clinicopathologic study of 66 patients. Am J Surg Pathol 1999;23:1184200 .

55. Kinney MC. The role of morphologic features of phenotype, genotype and anatomic site in defining extranodal T-cell and NK-cell neoplasms. Am J Clin Pathol 1999;111:S104-18.

56. Fergunson DJP. Intraepithelial lymphocytes and macrophages in the normal breast. Virchows Arch A (Pathol Anat) 1985;407:369-78. 